\title{
POSTER "HOPE" OBAMA DALAM KOMUNIKASI MASSA
}

\author{
Aji Windu Viatra \\ Fakultas Ilmu Pemerintahan dan Budaya, Universitas Indo Global Mandiri, Palembang \\ email:w1ndoe@yahoo.com
}

\begin{abstract}
Abstrak
Komunikasi menjadi hal yang pokok dalam berinteraksi dengan orang lain. Manusia memiliki kebutuhan yang signifikan dalam mengkomunikasikan dirinya terhadap orang lain bahkan dengan mahkluk lainnya. Komunikasi memberikan pengaruh dan peranan yang sangat bermanfaat dalam perkembangan manusia. Saat kita memulai beradaptasi di tempat yang baru, sangat diperlukannya suatu komunikasi yang aktif untuk mengenal budaya di tempat tersebut. Kegiatan ini menjadi hal yang alami, terjadi sesuatu tindakan spontan. Meskipun seringkali menghadapi kesulitan yang kadang kala menjadi suatu pengalaman yang berharga. Media-media komunikasi yang dipakai dalam menyampaikan pesan oleh komunikator dan diterima oleh komunikan memiliki fungsi dan manfaat yang variatif dan efesien. Proses komunikasi yang melibatkan suatu media juga seringkali memberikan suatu pemahaman yang berbeda-beda yang diterima oleh komunikan, banyak faktor yang mempengaruhi hal tersebut. Penelitian ini, membahas suatu topik kajian tentang poster Obama. Suatu media komunikasi massa dalam sebuah kampanye pemilihan Pemimpin Negara atau Presiden dan Wakil Presiden. Poster Obama telah memberikan kontribusi besar, atas keberhasilan Barack Obama menjadi Presiden Amerika Serikat yang ke-44, dan menjadi orang kulit hitam pertama yang memimpin negara Adidaya tersebut. Suatu program kampanye yang sangat menarik untuk dikaji dalam ilmu desain komunikasi visual, hal ini merupakan topik yang dapat menjadi inspirasi setiap insan dalam mengembangkan dirinya dalam berkomunikasi yang kreatif. Teori pendekatan penelitian ini, menggunakan analisis sudut pandang dari ilmu Komunikasi dan Semiotika Visual. Pendekatan ini, diharapkan dapat menguraikan unsur-unsur visual yang terdapat dalam Poster Obama, dan menjabarkan tanda, pesan, dan makna yang terkandung didalamnya.
\end{abstract}

Kata kunci : poster, kampanye Barack Obama, komunikasi, semiotika.

\section{OBAMA'S “HOPE” POSTER IN MASS COMMUNICATION}

\begin{abstract}
Communication is the main thing in interacting with others. Humans have a significant need in communicating themselves to others or even to the other kind of life creatures. Communication gives a very useful influence and role in human development. When we begin to adapt in a new place, we need an active communication to know the culture of that place. This activity becomes a natural thing and happens spontaneously. Although difficulties might appear, it could be a valuable experience.The communication media used for conveying the message ofa communicator and being received by the communicant havevaried and efficient functions. The communication process that involves a media often provides a different understanding that is received by the communicant, and there are many factors that influence it. This researchdiscusses a topic of study about Obama's poster. A mass communication media for the election campaign of the United Stat's President and Vice President. Obama's poster had made a big contribution to the success of Barack Obama to be the 44th President of the United States, and to be the first black people to
\end{abstract}


lead the Superpower country. it was a very interesting campaign program to be explored in visual communication design science, it was a topic that could inspire everyone in developing themselves in a creative communication. The approach theory used in this research was the analysis of the point of view of the Communication and Visual Semiotics sciences. This approach was expected to describe the visual elements contained in Obama's Poster, and described the signs, messages, and meanings contained on it.

Keywords: poster, Barack Obama campaign, communication, semiotics.

\section{PENDAHULUAN}

Komunikasi menjadi hal yang pokok dalam berinteraksi dengan orang lain. Manusia memiliki kebutuhan yang signifikan dalam mengkomunikasikan dirinya terhadap orang lain bahkan dengan mahkluk lainnya. Komunikasi memberikan pengaruh dan peranan yang sangat bermanfaat dalam perkembangan manusia. Saat kita memulai beradaptasi di tempat yang baru, sangat diperlukannya suatu komunikasi yang aktif untuk mengenal budaya di tempat tersebut. Kegiatan ini menjadi hal yang alami, terjadi sesuatu tindakan spontan. Meskipun seringkali menghadapi kesulitan yang kadang kala menjadi suatu pengalaman yang berharga.

Komunikasi merupakan ungkapan untukperasaan dan ide yang ada dalam benak pikiran manusia, menggunakan bermacammacam bahasa. Dan seni rupa salah satu dari bahasa-bahasa itu. Kata komunikasi (communication) berasal dari bahasa Latin communis yang berarti common: umum: bersama. Pengertian komunikasi adalah suatu proses pengiriman pesan yang terjadi antara dua pihak. Komunikasi dapat pula merupakan suatu jaringan sistem-sistem pertukaran tanda, isyarat lambang yang punya arti yang terjadi didalam suatu masyarakat dalam pemasaran, komunikasi sebagai suatu proses yang mana individu-individu sama-sama mengartikan dan membentuk pemikiran secara umum (commonness) atau perorangan (oneness) (Yongky, 2006). Fungsi komunikasi berkenaan dengan jenis yang berperan secara individu atau dikombinasikan sebagai: informasi, hiburan, intruksi atau persuasi. Konsep fungsi komunikasi membantu kita untuk menerangkan jenis-jenis pesan dan hubungan dengan motivasi dan kepuasan dalam berkomunikasi.

Media-media komunikasi yang dipakai dalam menyampaikan pesan oleh komunikator dan diterima oleh komunikan memiliki fungsi dan manfaat yang variatif dan efesien. Proses komunikasi yang melibatkan suatu media juga seringkali memberikan suatu pemahaman yang berbeda-beda yang diterima oleh komunikan, banyak faktor yang mempengaruhi hal tersebut. Kajian ini akan membahas suatu topik tentang Poster Obama. Suatu media komunikasi massa dalam sebuah kampanye pemilihan Pemimpin Negara atau Presiden dan Wakil Presiden. Poster Obama telah memberikan kontribusi besar, atas keberhasilan Barack Obama menjadi Presiden Amerika Serikat yang ke-44, dan menjadi orang kulit hitam pertama yang memimpin negara Adidaya tersebut. Suatu program kampanye yang sangat menarik untuk dikaji dalam ilmu desain komunikasi visual, hal ini merupakan topik yang dapat menjadi inspirasi setiap insan dalam mengembangkan dirinya dalam berkomunikasi yang kreatif. Media massa dan politik tidak bisa dipisahkan karena media memiliki posisi sebagai saluran komunikasi politik yang sangat efektif. Media massa memainkan peran yang sangat penting dalam proses politik. Ia memiliki kemampuan untuk membuat seseorang cemerlang dalam karier politiknya. Selain melalui media cetak dan elektronik, seiring dengan semakin bertambahnya pengguna internet saat ini, internet dapat dijadikan media kampanye yang efektif (Tabroni, 2012).

Kehadiran seni memiliki tujuan tertentu dari penyajinya, baik untuk dinikmati atau bernilai dalam makna dan dapat memberikan perubahan 
dari berbagai sisi kehidupan manusia. Era perkembangannya,senipunberkembangsejalan dengan peradapan manusia. Seni mempunyai jalur yang telah diikuti oleh para perupa, ada yang mengikuti jalur pengekspresian secara individu disebut fine art (seni murni) dan ada yang mengarah kepada media seni fungsional atau terapan yang disebut apllied art, misalnya desain. Seni desain yang cukup populer saat ini adalah desain komunikasi visual. Kualitas layanan dalam desain komunikasi visual bukan semata-mata bergantung kepada seni, namun kehadiran seni telah menjadikan desain komunikasi visual menjadi lebih bernilai, lebih berharga, dan bermakna.Waktu ke waktu dalam pertumbuhan seni rupa telah memberikan inspirasi, motivasi, dan pengalaman termasuk di dunia desain hingga melalui berbagai media atau multimedia.

Setiap orang dapat menyampaikan pesan, gagasan, atau perasaan melalui tanda, namun tidak dalam kualitas yang sama. Ada pesan yang diutarakan dengan tanda yang sederhana dan mudah di mengerti. Sebaliknya ada juga tanda yang rumit dan susah dimengerti. Persoalan kualitas tanda bukan pada sederhana atau rumitnya tanda, melainkan terletak pada pilihan tanda yang digunakan terkait daya serap khalayak sasaran. Tugas desainer grafis adalah mengidentifikasikan hingga akhirnya memilih dan memutuskan simbol atau tanda yang sesuai dengan konteksnya. Karya-karya desain komunikasi visual baik dalam wujud media poster, brosur, sampul buku, maupun animasi film dan sebagainya, pada dasarnya adalah sebuah jawaban atas persoalan komunikasi yang dihadapi. Karya tersebut bukan kreasi bebas, artinya di dalam proses hadirnya terjadi semacam dialog yang bermuara pada eksekusi desain seperti itu. Kebutuhan di satu pihak dan pihak lainnya adalah usulan pemecahan masalah atau ide. Munculnya suatu gagasan disebabkan oleh adanya persoalan atau kebutuhan. Gagasan merupakan wujud usaha mencari jalan keluar atau pemecahan masalah maka dari dasar masalah itu muncul yang disebut kreativitas.
Topik kajian ini menganalisis media grafis poster kampanye Obama. Poster Barack Obama dengan headline "Hope" karya seniman jalanan Shepard Fairey mempunyai pengaruh yang besar. Karya visual tersebut dianggap sebagai salah satu media yang ikut mengantarkan lelaki berkulit hitam itu menjadi presiden ke-44 Amerika Serikat. Program kampanye Obama berhasil mencapai kesuksesan luar biasa yang tidak lepas dari berbagai tantangan.

Kajian poster "Hope" Obama, menggunakan analisis sudut pandang dari ilmu komunikasi dan desain komunikasi visual. Pendekatan ini, diharapkan dapat menguraikan unsur-unsur visual yang terdapat pada Poster Obama, dan menjabarkan tanda, pesan atau makna yang terkandung di dalamnya. Pendekatan yang dilakukan akan menjalin rangkaian deskriptif dengan rujukan konsep komunikasi massa, tujuan teori komunikasi massa, peranan persepsi dalam komunikasi, persuasi, dampak dan manfaat komunikasi media massa (Werner, 2008).

\section{METODE}

Metode yang digunakan dalam penelitian ini yakni kualitatif. Surachmad (1978), dalam menyatakan bahwa cara utama yang dipergunakan untuk mencapai tujuan, misalnya untuk menguji serangkaian hipotesis, dan dengan menggunakan teknik serta alat-alat tertentu". Pengumpulan data dalam penelitian ini ditujukan untuk memperoleh data-data relevan dengan topik penelitian ini, sehingga memiliki keakuratan dan reliabilitas yang baik.

Metode kualitatif yang digunakan dalam penelitian ini lebih banyak mencatat dan menerima data tentang objek, yak poster Hope Obama, kemudian dianalisis dan diuraikan secara sistematis dengan menggunakan teoriteori relevan dan sesuai dengan pendekatan yang digunakan. Pendekatan digunakan dalam penelitian ini adalah ilmu komunikasi dan semiotika visual.

Dalam proses pengumpulan data yang dibutuhkan, penelitian ini menggunakan beberapa teknik, yakni observasi, wawancara, 
dan dokumentasi. Pertama, teknik observasi merupakan metode yang melakukan pengenalan terhadap berbagai fenomenafenomena yang berhubungan dengan obyek penelitian. Prakteknya dilakukan pencatatanpencatatan secara sistematis fenomena tersebut. Kedua, teknik wawancara, merupakan metode pelengkap dari beberapa metode yang telah ditemukan diatas. Teknik ini digunakan untuk memperoleh metode-metode diatas dengan jalan melakukan interview langsung dengan kalangan akademis, para desainer grafis dan orang-orang yang memiliki hubungan dengan penelitian. Ketiga, teknik dokumentasi adalah cara-cara yang diperlukan pada suatu penelitian dengan jalan mendokumentasikan sesuatu data yang dianggap penting. Teknik ini ditempuh sebagai salah satu cara yang diperlukan dalam mengumpulkan data bersifat visual seperti gambar atau foto-foto, maupun literaturliteratur yang berfungsi untuk melengkapi data-data lain. teknik dokumentasi dilakukan dalam penelitian ini menggunakan alat pencatat dokumen seperti Kamera Digital SLR, Scanner, Computer Graphic dan Internet.

Adapun terkait dengan proses pengumpulan data dapam penelitian ini dapat disampaikan dengan tahapan, yakni:

a) Mengidentifikasikan elemen-elemen visual yang ada dalam poster Hope Obama dengan mengambil elemen-elemen visual dominan

b) Menganalisa makna dalam elemenelemen tersebut. Elemen-elemen visual akan didekonstruksikan kemudian dicari fungsinya sebagai pembawa pesan dari sudut tinjauan Semiotika Visual

c) Menganalisa hubungan antar elemen dengan makna, sehingga ditemukan makna utama dari sample-sample karya Shepard Fairey tersebut. Dari proses ini akan diketahui dampak yang ditujukan oleh Kampanye Barack Obama dalam mempersuasi konsumennya.

d) Mengambilkesimpulan, pengaruh,peranan, fungsi dan tujuan dalam penciptaan karya desain poster Hope Obama sebagai media komunikasi massa.
Kemudian, terkait dengan teknik analisis data yang digunakan dalam penelitian ini, yakni jenis analisis deksriptif kualitatif, yaitu proses analisa dengan menggunakan data yang diperoleh, kemudian dilakukan seleksi untuk mencari sample yang dianggap memenuhi kriteria yang telah ditetapkan sebagai tujuan dari penelitian ini, sehingga jalannya penelitian ini dapat berjalan sesuai dengan tujuan semula. Jadi pada penelitian ini yang diteliti adalah tentang poster sebagai media komunikasi visual massa meliputi pengertian, perkembangannya, fungsi, tujuan dan pemahaman makna-makna visual yang menjadi penanda dari media poster. Serta sebagai obyek penelitian adalah poster Hope Obama karya Shepard Fairey, yang memiliki makna sebagai media propagandis.

\section{HASIL DAN PEMBAHASAN \\ 1. Seni dan Politik: Kampanye Politik Melalui Media Grafis}

Komunikasi untuk mengungkapkan perasaan dan ide yang ada dalam benak pikiran manusia, menggunakan bermacam-macam bahasa. Seni rupa salah satu dari bahasabahasa itu. Kata komunikasi (communication) berasal dari bahasa Latin communis yang berarti common, yang bermakna umum atau bersama. Pengertian komunikasi adalah suatu proses pengiriman pesan yang terjadi antara dua pihak. Komunikasi dapat pula merupakan suatu jaringan sistem-sistem pertukaran tanda, isyarat lambing yang punya arti yang terjadi didalam suatu masyarakat dalam pemasaran, komunikasi sebagai suatu proses yang mana individu-individu sama-sama mengartikan dan membentuk pemikiran secara umum (commonness) atau perorangan (oneness) (Yongky, 2006). Fungsi komunikasi berkenaan dengan jenis yang berperan secara individu atau dikombinasikan sebagai: informasi, hiburan, intruksi atau persuasi. Konsep fungsi komunikasi membantu kita untuk menerangkan jenis-jenis pesan dan hubungan dengan motivasi dan kepuasan dalam berkomunikasi.

Seni mengandung pandangan-pandangan pribadi tentang peristiwa-peristiwa dan obyek yang umum akrab dengan kita semua. Situasi 
kemanusian mendasar mengalami sirkulasi konstan sebagai tema-tema seni. Semua fungsi karya-karya seni adalah sebagai media pribadi seorang seniman, hal ini tentu tidak mencegah fungsi karya-karya seni bermaksud untuk melayani tujuan-tujuan lainnya. Semua karya seni menunjukan suatu fungsi sosial, saat karya-karya itu diciptakan. Karya seni yang telah diciptakan dalam menanggapi hasrat yang paling rahasia dan sangat pribadi itu, bagaimanapun berfungsi dalam suatu konteks yang diharapkan dapat mengundang tanggapan dan sambutan masyarakat. Edmund menunjukan suatu karya seni memiliki fungsi sosial apabila: 1. Karya seni mencari atau cenderung mempengaruhi perilaku kolektif orang banyak, 2. Karya itu diciptakan untuk dilihat atau digunakan, khususnya di dalam situasi-situasi umum, dan 3. Karya seni itu mengekspresikanataumenjelaskanaspek-aspek tentang eksestensi sosial atau kolektif sebagai lawan dari bermacam-macam pengalaman personal maupun individual (Edmund, 1967).

Suatu kondisi fungsi sosial karya seni secara individu menanggapi seni dengan kesadaran bahwa ia merupakan salah satu anggota dari suatu kelompok, yakni sebuah kelompok yang dalam beberapa hal dkarakterisasikan atau didorong untuk melaksanakan sesuatu oleh karya seni yang ia saksikan. Seni umum sangat jelas menampilkan suatu fungsi sosial, banyak karya seni yang diusahakan untuk mempengaruhi perilaku sosial. Karya seni mampu membuat kita tertawa, sedih, gembira, melakukan aksi politik dan sosial atau melihat situasi sosial kita dalam caracara yang sebelumnya tidak tampak. Seni dapat mempengaruhi perilaku orang-orang dalam berbagai kelompok, mempengaruhi cara berpikir atau merasakan dan kadang-kadang juga mempengaruhi cara untuk berbuat.

Kehadiran seni memiliki tujuan tertentu dari penyajinya, baik untuk dinikmati atau bernilai dalam makna dan dapat memberikan perubahan dari berbagai sisi kehidupan manusia. Era perkembangannya, seni pun berkembang sejalan dengan peradapan manusia. Seni mempunyai jalur yang telah diikuti oleh para perupa, ada yang mengikuti jalur pengekspresian secara individu disebut fine art (seni murni) dan ada yang mengarah kepada media seni fungsional atau terapan yang disebut apllied art (desain). Seni desain yang cukup populer saat ini adalah desain komunikasi visual. Kualitas layanan dalam Desain Komunikasi Visual bukan semata-mata bergantung kepada seni, namun kehadiran seni telah menjadikan desain komunikasi visual menjadi lebih bernilai, lebih berharga, dan bermakna (Umar, 2009). Waktu ke waktu dalam pertumbuhan seni rupa telah memberikan inspirasi, motivasi, dan pengalaman termasuk di dunia desain hingga melalui berbagai media atau multimedia.

Hasil perancangan komunikasi visual telah merambah ke dalam berbagai bidang dalam memenuhi kebutuhan manusia, utamanya komunikasi secara visual. Desain Komunikasi Visual mengandung kekuatan dan pengaruh sangat besar dalam mempersuasi komunikan, salah satu alasan inilah yang sering digunakan para pengusaha produk dan jasa, sampai juga bagi para-para politik yang membutuhkan jasa para perancang Desain Komunikasi Visual atau graphic designer.

Setiap orang dapatmenyampaikan pesan, gagasan, atau perasaan melalui tanda, namun tidak dalam kualitas yang sama. Ada pesan yang diutarakan dengan tanda yang sederhana dan mudah di mengerti. Sebaliknya ada juga tanda yang rumit dan susah dimengerti. Persoalan kualitas tanda bukan pada sederhana atau rumitnya tanda, melainkan terletak pada pilihan tanda yang digunakan terkait daya serap khalayak sasaran. Tugas desainer grafis adalah mengidentifikasikan hingga akhirnya memilih dan memutuskan simbol atau tanda yang sesuai dengan konteksnya.

Karya-karya Desain Komunikasi Visual baik dalam wujud media poster, brosur, sampul buku, maupun animasi film dan sebagainya, pada dasarnya adalah sebuah jawaban atas persoalan komunikasi yang dihadapi. Karya tersebut bukan kreasi bebas, artinya di dalam proses hadirnya terjadi semacam dialog yang bermuara pada eksekusi desain seperti itu. 
Kebutuhan di satu pihak dan pihak lainnya adalah usulan pemecahan masalah atau ide. Munculnya suatu gagasan disebabkan oleh adanya persoalan atau kebutuhan. Gagasan merupakan wujud usaha mencari jalan keluar atau pemecahan masalah maka dari dasar masalah itu muncul yang disebut kreativitas.

Iklan politik dibutuhkan sebagai jalan pintas yang instan dan cepat untuk perkenalkan diri pada rakyat, karena kebanyakan kandidat tidak dekat dengan rakyat. Iklan politik digunakan untuk memperkenal diri sebagai calon pemimpin, menyosialisasikan program kerja yang akan dijalankan jika terpilih. Iklan politik juga dipergunakan untuk mempengaruhi calon pemilih ketika memilih

Iklan politik penting dalam menghadapi persaingan politik, namun sangat di sayangkan langkah-langkah membranding figur kurang tepat. Iklan politik di Indonesia banyak menggunakan konsep hardsell dan berpenampilan paritas, para calon pemimpin atau peserta pemilu sangat menyukai konsep hardsell, karena dianggap mujarab mendongkrak popularitas seluruh elemen parpol dan calon pemimpin tersebut. Karena politisi kita terbuai dalam euphoria pemilihan langsung dan serta merta merasa dirinya menjadi kaum selebritas. Para kaum politik dalam pikirannya dengan memasang wajah mereka sebanyak mungkin, pemilih akan tertarik. Mana mungkin sebuah kepercayaan dapat dibeli dengan senyuman foto sang calon pemimpin. Sehingga dibutuhkan komunikasi yang tepat, menurut paradigma Lasswell (Effendy, 2005) komunikasi adalah proses penyampaian pesan oleh komunikator kepada komunikan melalui media yang menimbulkan efek tertentu.

Iklan politik yang baik dan jujur kalau keberadaannya dapat mengangkat masalah yang benar-benar ada dalam kehidupan rakyat dan bisa menawatkan solusinya dengan alasan yang dapat dipercayai dalam alam reformasi seperti sekarang ini, masyarakat secara terbuka tidak akan terpengaruh oleh janji politik yang manis di mulut, namun pahit dalam kenyataan kehidupan sehari-hari. Masyarakat Indonesia wajib tahu bagaimana memilah mana pemimpin narsis dan mana pemimpin sejati melalui iklan politik kampanye partai politik (Sumbo, 2008).

Topik kajian ini akan menganalisis media grafis poster kampanye Obama. Poster Barack Obama dengan headline "Hope" karya seniman jalanan Shepard Fairey punya pengaruh besar. Karya visual tersebut dianggap sebagai salah satu media yang ikut mengantarkan lelaki berkulit hitam itu menjadi presiden ke-44 Amerika Serikat. Program kampanye Obama berhasil mencapai kesuksesan luar biasa yang tidak lepas dari berbagai tantangan.

\section{Obama dan Poster "Hope"}

Poster "Hope" Obama yang di rancang oleh Shepard Fairey, yang mana dikenal secara luas hingga menjadi ikon yang sangat berarti di kampanye Obama untuk menjadi salah satu peserta calon Presiden AS. Poster dengan gaya stensil gambar Obama dengan warna solid merah di bagian kiri wajah, biru pastel dan putih dengan warna keabu-abuan mendekati coklat di wajah bagian kanan, dengan kata "Hope" (poster ini mempunyai variasi kata yang berbeda-beda yakni "Progress" dan "Change") yang diletakan di bawah. Komposisi simpel dan warna terang berusaha mencitrakan sosok lelaki itu sebagai pembawa harapan sesuai dengan kata "hope" pada bagian bawah, serta terdapat logo kampanye Obama yang berada di sebelah dada kiri bawah gambar Obama sebagai identitas tim kampanye. Secara visual, poster "Hope" ini memang memikat. Memakai jas dan dasi, Obama ditampilkan dengan wajah agak mendongak ke kanan atas dan sorot mata tajam. Gambar Obama menyerupai silhouette memberikan sebuah ekspresi yang meyakinkan dengan kesan serius dan santai dalam menghadapi masalah, serta tatapan tajam yang menggambarkan hal yang detail. Adapun, poster sebagaimana dimaksud adalah sebagai berikut. 


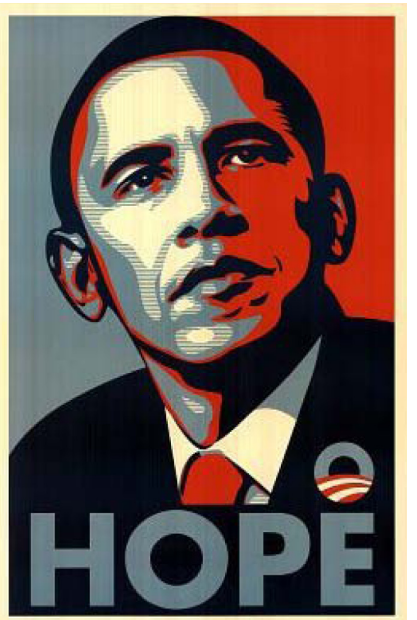

Gambar 1. Poster "Hope" Obama, Karya Shepard Fairey

(Sumber : https://obeygiant.com/obama-hope/)

Rancangan poster tersebut dibuat hanya dalam satu hari, dan pertama kali dicetak sebagai poster. Fairey menjual 350 buah poster di jalanan secara cepat setelah mencetak semuanya. Pendistribusian poster ini menjadi semakin luas, dalam bentuk gambar digital maupun aksesoris selama pemilihan presiden 2008 berlangsung. Penjualan itu secara bebas setelah mendapatkan persetujuan dari tim kampanye Obama. Poster ini menjadi salah satu simbol Obama yang dikenal luas dalam hal menyampaikan pesan dengan tampilan yang bervariasi dan ditambah produk tiruan lainnya.

Shepard Fairey adalah seorang Street Art yang sebelumnya telah menciptakan beberapa karya seni jalanan tentang kritik terhadap politik, seperti mengkritik pemerintahan George W. Bush. Karya poster Fairey mulai dikenal ketika Yosi Sergant salah satu tim kampanye publikasi Obama, di akhir bulan Oktober 2007. Sergant meminta Fairey merancang karya seni dalam rangka mendukung Obama. Kemudian ia mulai menghubungi tim kampenye Obama, mencoba mendapatkan ijin untuk Fairey merancang poster Obama dimana beberapa minggu sebelum waktu kampanye di mulai. Poster "Hope" Obama tersebut, dibuat berdasarkan foto Obama sebagai berikut.

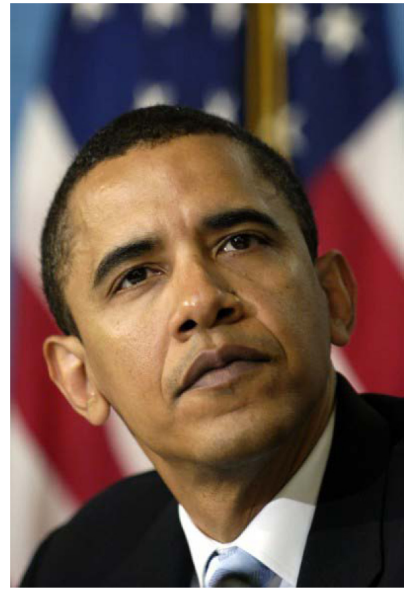

Gambar 2. Foto Barack Obama sumber : http://www.doobybrain.com/Original photograph that inspired Obama "Hope" poster discovered.

Proses perancangan poster ini, di awali Fairey mencari foto Obama dengan menggunakan Google Image Search (April 2006, ide foto ditemukan dari koleksi karya foto freelancer Mannie Garcia dari The Associated Press) dan rancangan poster diselesaikan dalam satu hari. Karya gambar asli poster menggunakan kata "Progress" dan menonjolkan karakter "Obey" Fairey, simbol asosiasi dengan Andre the Giant has a Posse gerakan seni jalanan, dan juga disertakan logo kampanye Obama. Poster ini mendapatkan banyak pujian, original dan unik. Bahkan menjadi bagian bentuk dari seniman kontemporer, gaya tampilan memberikan inspirasi dari calon kandidat, serta merubah bentuk baku warna dan gaya lama, poster ini memiliki pesan dan makna yang dapat memberikan harapan dalam perubahan yang lebih baik.

Sejak awal tahun 2009, poster "Hope" dijadikan koleksi permanen The National Portrait Gallery di tengah kota Washington DC. Dipajang di lantai pertama dekat pintu masuk, karya dengan label "New Arrivals" ini mengundang perhatian. Pengunjung dari sejumlah negeri tak henti-henti memelototinya.

Poster ini adalah produk seni rupa paling terkenal di AS saat ini. Fairey, seniman jalanan 
asal Los Angeles itu, pun masyhur. Popularitas bermula dari suatu kontroversi. Poster itu dinilai mengapropriasi (bahasa lainnya, menjiplak) foto Mannie Garcia saat bertugas untuk The Associated Press (AP) tahun 2006. Namun, Fairey merasa dia terlindungi doktrin "fair use" ketentuan hukum AS yang membolehkan penggunaan tanpa izin atas karya berhak cipta untuk kepentingan tertentu secara terbatas dan adil. Hingga kini, perdebatan soal ini belum berhenti.

Sebagian kalangan menyamakan keberanian pemuda itu dengan uji coba Andy Warhol yang mencetak merek minuman Coca-Cola untuk karya Pop Art. Kalangan lain membandingkan kekuatan Fairey dengan poster James Montgomery Flagg, "I Want You for the US Army". Propaganda "Uncle Sam" tahun 1917 itu digunakan untuk merekrut tentara zaman perang. Poster ini memainkan sangat penting pada kampanye dan pemilu presiden AS tahun 2008. Lewat bahasa visual, karya ini ikut meyakinkan masyarakat bahwa Obama menjanjikan perubahan. Masyarakat ternyata menghendaki perubahan itu (Khoiri, Kompas.com).

\section{Tanda dan Makna Visual Poster "Hope" Obama}

Gayatampilandesainposter"Hope"Obama, yang dirancang Shepard Fairey memiliki karakter kuat dalam menampilkan figur Barack Obama. Dikaitkan dengan desain grafis, gaya memberi kesan berkuasa visual estetik dari fakta waktu dan tempat. Analisis gaya desain grafis di poster ini, berkaitan dengan inspirasi gaya desain Plakatstil dan Pop Art. Elemenelemen poster dari bentuk, warna dan tipografi. Unsur bentuk bidang dua dimensi memiliki ciri-ciri visual geometrik sederhana dan khas. Interaksi bentuk mengandung posisi, ruang dan arah yang menarik dan memberikan kesan dinamis dengan makna bersahaja menatap ke depan penuh keyakinan.

Desain poster ini lebih fungsional, dengan meninggalkan simbolisme dan beralih pada rasionalisme. Visual yang digunakan telah meninggalkan unsur hiasan, tidak menyertakan dramatisasi, bayangan padat, gerak nyata yang sederhana. Poster Obama memiliki kesederhanaan dalam proses berpikir dengan hasil yang dapat memberikan pencerahan bagi masyarakat Amerika Serikat dan masyarakat dunia menjadi sebuah harapan besar yang harus diraih.
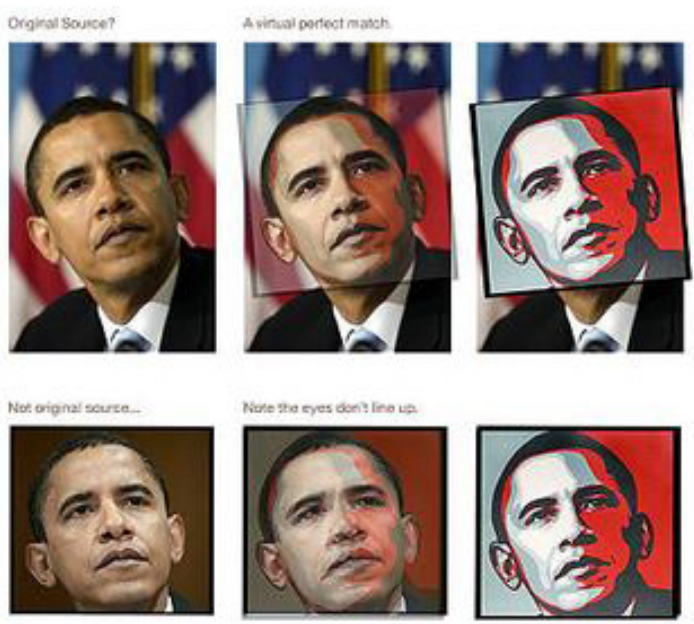

Gambar 3. Proses Desain Poster Obama http://en.wikipedia.org/wiki/File:Fairey_poster_photo source\%3F,_by_stevesimula.jpg

Warna poster sebagai unsur datar dan menarik perhatian. Komposisi warna merah, putih, dan biru menjadi bagian solid, disini dapat dilihat tanda simbolisasi dari bendera Negara Amerika Serikat. Penggunaan warna primer ini memiliki tanda-tanda identitas sebagai pembeda dan ciri khas sebuah Negara. Sebuah warna selalu mempunyai arti yang berbeda pada budaya yang berbeda. Namun secara umum warna-warna bisa diartikan berdasarkan psikoloi warna. Warna merah, Warna yang dapat menimbulkan emosi dan paling cepat menaikkan detak jantung dan hembusan nafas. Warna merah juga diartikan sebagai warna cinta meskipun juga sangat cocok menggambarkan konfrontasi dan tidak membantu dalam suasana negosiasi. Warna putih, Warna putih mensimbolkan kemurnian dan kesucian serta merefleksikan cahaya dan identik dengan unsur-unsur panas. Warna putih sangat populer karena bersih netral dan cocok ditempatkan denagn warna apapun. Dan 
warna biru, Sebagai warna langit dan laut, biru merupakan salah satu warna yang popular. Biru memberikan reaksi yang bertolak belakang dengan apa yang diberikan oleh warna merah. Kesan damai terjadi hanya diberikan oleh warna biru ini, membuat tubuh memproduksi senyawa-senyawa kinerja yang ceria dan menyenangkan. Warna biru sering dipakai sebagai warna tempat tidur dan diartikan dingin dan bebas dari tekanan.

Kata "Hope" di dalam poster Obama, memberikan harapan Amerika Serikat dari sosok pimpinan yang dapat memberikan perubahan dari segala bidang secara rill. Tipografi yang digunakan memiliki bentuk yang tebal dan sedikit, mengartikan makna konotatif sebuah harapan nyata. Kuat dan tegas dicerminkan dari kata yang menjadi headline poster ini telah mempersuasi masyarakat Amerika, bahkan dunia.

Rancangan poster Obama secara keseluruhan menyerupai gaya pop art. Pengertian pop art adalah sebuah art movement yang berkembang dari tahun 1960-an yang mana mengambil inspirasi dari kaum pinggiran (non-elite) dan popular culture. Pop art muncul pada pertama kalinya pada tahun 1962 beberapa kali di billboard advertising, commercial logos, lettered signs, dan comic strips. Karakteristik dari Pop Art adalah penggunaan fotografi yang seperti dalam teknik lukisan dan perhatian mendetail pada seni pahat, photomontage, dan collage (susunan benda-benda dan potonganpotongan kertas yang ditempelkan pada bidang datar). Inspirasi gaya desain grafis yang dipakai Fairey ini mencoba pendekatan yang lebih menimbulkan kesan suasana keakraban, menerima segala rupa bentuk fisik dan tanpa memiliki batasan yang baku beku dari wilayah tingkatan apapun.

Jenis poster Obama merupakan poster non komersial atau sosial berdasarkan tujuan periklanannya. Poster untuk melayani kepentingan umum bersifat sosial kemasyarakatan dasarnya adalah sarana penyampaian atau informasi yang bersifat sosial (Gumilar, 2003). Dan karakter dalam poster tersebut memiliki simplicity (kesederhanaan), unity (kesatuan), surprise (kejutan), di dalam suatu desain haruslah ada, sebagai daya tarik atau penangkap pandang. Dari sini dapat dikembangkan kesegala arah untuk menuruti atau mengikuti garis seni dan selanjutnya bisa dikatakan bahwa bagian tersebut menggerakkan mata ke suatu arah, dan karenanya menghilangkan sifat statis di dalam komposisi.

Desain yang baik hendaklah mempunyai permulaan dan akhir, harus mempunyai kejutan atau tekanan, mempunyai arti balance dan ritme. Dari kejutan atas pernyataan permulaan selanjutnya dikembangkan sebagai variasivariasi dan pembelokan-pembelokan yang masih selaras sampai pada bagian akhir.

\section{Poster "Hope" Obama dalam Komunikasi Massa}

Komunikasi massa adalah komunikasi yangdisalurkan oleh pemancar pemancar yang berbentuk audio dan atau visual. Komunikasi massa akan lebih mudah dan lebih logis bila didefinisikan menurut bentuknya: televisi, radio, surat kabar, majalah, film, dan buku. (Nurdin, 2004:11). Sebuah poster memiliki kekuatan daya tarik yang luar biasa. Secara visual dapat menarik rasa simpatik yang membuat kita mencerna daya pikir dalam mengambil suatu keputusan. Seperti halnya poster "Hope" Obama, telah menjadi sebuah simbol identitas yang khas dalam program kampanye yang dilakukannya. Poster ini merupakan sebuah media cetak komunikasi massa. Dan memiliki peranan penting dalam proses kampanye pemilihan Presiden Amerika Serikat.

Media komunikasi massa Obama memberikan masyarakat sarana untuk mengambil keputusan dan membentuk opini kolektif yang bisa digunakan untuk memahami diri sendiri dan lingkungan sekitarnya, seperti halnya dengan dampak dari poster Obama yang dapat memberikan nilai-nilai perubahan dalam masyarakat Amerika Serikat. 


\section{a. Persepsi untuk Obama}

Media poster Obama bukanlah suatu hal yang baru di era zaman sekarang, namun tidak dapat kita pungkiri suatu poster masih tetap memiliki kekuatan yang kadang kala sulit diprediksikan. Secara konsep komunikasi massa, dapat dikaitkan dengan arah komunikasi massa yang menjangkau audiens besar, khususnya untuk masyarakat Amerika Serikat. Namun pengaruh yang dihasilkan oleh poster Obama telah memberikan efek fantastis terhadap masyarakat dunia. Muncul suatu harapan baru, perubahan yang diharapkan masyarakat dunia atas permasalahan dunia saat ini. Barack Obama memiliki daya tarik yang luar biasa kepada dunia dengan pesan-pesan yang disampaikannya melalui pidato, ceramah, kampanye perubahan dunianya dan ekspresi yang penuh harapan di dalam posternya.

Poster memiliki sifat waktu sementara, berbeda halnya dengan poster Obama. Sejak awal tahun 2009, poster "Hope" dijadikan koleksi permanen The National Portrait Gallery di tengah kota Washington DC. Dipajang di lantai pertama dekat pintu masuk, karya dengan label "New Arrivals". Apresiasi poster yang menjadi contoh bagi masyarakat dunia.

Perwujudan media kampanye Barack Obama berupa poster, meskipun kita ketahui terdapat program-program lainnya, seperti media televisi, radio, dan internet. Mediamedia yang digunakan tim sukses kampanye Obama menghasilkan persepsi dari masyarakat sebagai komunikan yang interaktif. Harapan ini merupakan tujuan yang diinginkan oleh para komunikator, setiap media mengandung pesan-pesan yang ditujukan kepada para peserta pemilih dan simpatisan, dan membuat keputusan yang benar dalam respon dan tingkah lakunya. Setiap media komunikator massa sering kali menjadi permasalahan ketika proses informasi tersebut sampai dalam tahap orang untuk memahaminya. Pemahaman yang berbeda oleh setiap insan komunikan menjadi suatu indikasi masalah yang mendasar. Mengatasi masalah ini, komunikator harus aktif dalam memberikan informasi yang tepat, akurat dan jelas serta selalu memiliki mediamedia alternatif yang mendukung tercapainya target tujuan.

Persepsi visual yang dihasilkan oleh poster Obama, memiliki point interesting yang kuat. Pada saat orang melihatnya, secara beberapa waktu sudah dapat ditangkap jelas sosok silhoutte Obama secara indera visual. Hal ini ditunjang oleh image Obama sendiri yang memiliki kharisma dan jiwa pemimpin yang dapat menganyomi masyarakatnya. Warna poster yang digunakan merupakan bukan hal yang asing bagi warganya, dikarenakan warna tersebut merupakan warna dominan dari bendera Amerika Serikat. Jadi, komunikan dapat dengan jelas menangkap dan memahami simbol calon presiden yang mereka akan pilih berdasarkan pengambilan keputusan yang tepat.

Mengutip penjabaran tentang retorika visual oleh Scott, menunjukkan tiga cara berpikir tentang gambar di media massa, sebagai gambaran nyata dari realitas, sebagai alat pembawa daya tarik afektif atau emosional, sebagai kombinasi simbol-simbol yang rumit untuk menyusun argumentasiargumentasi retoris. Persepsi visual dari poster Obama, menjadi gambaran nyata ketika orang mencoba memahami Obama dan pemakaian simbol-simbol negara meningkatkan rasa nasionalisme dengan nilai tinggi. Aktifitas yang telah dilakukan Obama menjadi faktor penting dan daya tarik berupa kharisma yang dimiliki oleh Obama menjadi senjata ampuh dalam membuat keputusan untuk memilihnya sebagai Presiden AS.

\section{b. Persuasi dari Obama}

Kehadiran Barack Obama dalam kancah dunia politik Amerika Serikat telah memberikan pengaruh yang luar biasa. Puncaknya, ketika Obama terpilih menjadi Presiden AS yang ke44. Disamping attitude yang dimilikinya, dalam masa kampanye Obama telah menciptakan program-program yang kreatif dan efektif untuk menarik perhatian warga Amerika Serikat. Salah satunya yaitu poster "Hope" Obama untuk mempersuasi para pemilik suara, penentu masa depan negara tersebut. 
Bentuk komunikasi paling mendasar adalah persuasi. Meskipun tidak dapat dipungkiri, ada faktor lain yang dapat merubah sikap dalam mengambil keputusan. Namun poster Obama cukup memberikan peranan yang cukup positif dalam menentukan pilihan. Olson dan Zanna mendefinisikan persuasi sebagai "perubahan sikap akibat paparan informasi dari orang lain". Sikap pada dasarnya adalah tendensi kita terhadap sesuatu. Sikap adalah rasa suka/tidak suka kita pada atas sesuatu. Konsep lain yang terkait erat dengan sikap adalah keyakinan, atau pernyataan-pernyataan yang dianggap benar oleh seseorang.

Sikap dalam mempengaruhi keputusan, memiliki unsur rasa suka terhadap sesuatu. Poster Obama mengkomunikan secara efektif dalam meningkatkan rasa suka itu. Secara visual, poster ini memiliki cita rasa seni yang sangat komunikati dalam gaya yang bernuansakan suasana menyatu dengan lingkungan sekitar dan tidak memberikan rasa formal yang terlalu berlebihan. Ini menjadi elemen pendukung untuk menyukai Obama dengan gaya grafisnya. Obama telah membuat orang yakin, untuk membawa Amerika Serikat menuju masa depan yang lebih baik, dengan "harapan" dan "perubahan" dalam misinya. Timbal balik yang didapatkan Obama berupa sebuah tindakan dan respon yang positif untuk memberikan suaranya kepada Obama. Sulit untuk memprediksikan masa depan, namun dengan program dan langkah yang tepat semua itu bukanlah hal yang mustahil. Harapan yang besar, ini dapat menjadi kenyataan yang indah. Kerjasama, semangat dan nilai-nilai budaya masyarakat yang selalu dijunjung tinggi menjadi kekuatan yang nyata.

\section{KESIMPULAN}

Program kampanye Obama merupakan langkah-langkah yang sudah akrab bagi zaman masa kini. Sebuah terobosan kampanye yang luar biasa dengan perencanaan matang, dimana melibatkan segala unsur dan attitude yang tak diragukan, khususnya seni dan teknologi. Karya seni yang ditampilkan dalam konteks politik, dapat mendapat dukungan respon baik dari publik sesuai dengan tujuan dan manfaatnya dapat dirasakan secara positif. Nilai-nilai yang dihasilkan dalam masyarakat merupakan hasil dari buah pemikiran pemahaman dari berbagai sumber referensi yang didapatkan dan kebutuhan yang sesuai dengan budaya masyarakat tersebut.

Poster "Hope" Obama, telah menjadi sebuah simbol identitas yang khas dalam program kampanye yang dilakukannya. Poster ini merupakan sebuah media cetak komunikasi massa. Dan memiliki peranan penting dalam proses kampanye pemilihan Presiden Amerika Serikat. Media komunikasi massa Obama memberikan masyarakat sarana untuk mengambil keputusan dan membentuk opini kolektif yang bisa digunakan untuk memahami diri sendiri dan lingkungan sekitarnya, seperti halnya dengan dampak dari poster Obama yang dapat memberikan nilai-nilai perubahan dalam masyarakat Amerika Serikat.

Perwujudan media kampanye Obama berupa poster, meskipun kita ketahui terdapat program-program lainnya, seperti media televisi, radio, dan internet. Media-media yang digunakan tim sukses kampanye Obama menghasilkan persepsi dari masyarakat sebagai komunikan yang interaktif. Harapan ini merupakan tujuan yang diinginkan oleh para komunikator, setiap media mengandung pesan-pesan yang ditujukan kepada para peserta pemilih dan simpatisan, dan membuat keputusan yang benar dalam respon dan tingkah lakunya. Setiap media komunikator massa sering kali menjadi permasalahan ketika proses informasi tersebut sampai dalam tahap orang untuk memahaminya. Pemahaman yang berbeda oleh setiap insan komunikan menjadi suatu indikasi masalah yang mendasar. Mengatasi masalah ini, komunikator harus aktif dalam memberikan informasi yang tepat, akurat dan jelas serta selalu memiliki mediamedia alternatif yang mendukung tercapainya target tujuan.

Sikap dalam mempengaruhi keputusan, memiliki unsur rasa suka terhadap sesuatu. Poster Obama mengkomunikan secara efektif dalam meningkatkan rasa suka itu. 
Secara visual, poster ini memiliki cita rasa seni yang sangat komunikati dalam gaya yang bernuansakan suasana menyatu dengan lingkungan sekitar dan tidak memberikan rasa formal yang terlalu berlebihan. Ini menjadi elemen pendukung untuk menyukai Obama dengan gaya grafisnya.

Poster Obama merupakan sebuah karya seni jalanan yang sukses membawa perubahan dalam cara orang berpikir dan menentukan sikapnya. Seni tetaplah sebagai seni terlepas bahwa seni dalam kenyataannya sering mendapat muatan politik. Seni akan tetap indah dan bernilai ditengah muatanyang menyertainya sepanjang seni tidak keluar dari pakem-pakemnya. Program kampanye Obama di antaranya yang diwujudkan dengan poster seperti ini merupakan salah satu contoh yang dapat meningkatkan wawasan dan pengetahuan dalam dunia politik, misalnya dalam konteks Indonesia.

\section{DAFTAR PUSTAKA}

Effendy, Onong. 1994. Ilmu Komunikasi: Teori dan Praktek. Bandung: Rosdakarya.

Feldmen, Burke, Edmund. 1967. Art as Image and Idea. Englewood Clifss. New Jersey: The University of Georgia. Prentice Hall, Inc.

Gumilar, Rino. 2003. Memahami Poster Sosial melalui Pendekatan Ilustrasi simbolis (Studi: Kasus Poster Pemenang Lomba Poster HIVIAIDS dan Narkoba Yayasan Galang Yogyakarta dan Ford Foundation). Yogyakarta: Galang.
Hadi, M. Umar. 2009.Irama Visual (Seni dalam Desain Komunikasi visual). Yogyakarta Jalasutra.

Nurdin. 2004. Komunikasi Massa. Jakarta: Cespur.

Obama, Street Art, dan Demokrasi. 2010. Poster Barack Obama "Hope" karya Shepard Fairey. Retrieved 24 August 2018, from https://ilhamkhoiri.wordpress. com/2010/12/24/obama-street-art-dandemokrasi/

Obama Hope. 2018. Poster. Retrieved 24 August 2018, from https://obeygiant.com/ obama-hope/

Proof Magazine 2001. 2018. Shepard Fairey. Retrieved 11 September 2018, from https:// obeygiant.com/articles/proof-magazine-22001/

Safanayong, Yongky. 2006. Desain Komunikasi Visual Terpadu. Jakarta: Arte Intermedia.

Surachmad, Winarno.1978. Dasar dan Teknik Research. Bandung:Tarsito.

Tinarbuko, Sumbo. 2008. Seminar Akademik: "Iklan Politik dalam Perspektif Dekave". Fakultas Seni Rupa ISI Yogyakarta, pada tanggal 10-11 Desember 2008.

Tinarbuko,Sumbo.2010.Semiotika Komunikasi Visual. Yogyakarta: Jalasutra.

Tabroni, Roni. 2012. Komunikasi Politik pada Era Multimedia. Jakarta: Simbiosa Rekatama Media. 